\title{
Information Content in International Equity Volatility on Yuan's Depreciation
}

\author{
Amanjot Singh ${ }^{1 *}$ and Harminder Singh ${ }^{2}$ \\ 'Tutor and PhD Scholar, Department of Finance, Deakin University, Melbourne - 3125, Victoria, Australia; \\ amanjot.singh@deakin.edu.au \\ ${ }^{2}$ Associate Professor, Department of Finance, Deakin Business School, Deakin University, Melbourne - 3125, \\ Victoria, Australia; harminder.singh@deakin.edu.au
}

\begin{abstract}
We investigate whether depreciation of USD-CNY exchange rate causes direct or indirect effects on conditional variances in the international equity markets, especially of Japanese, ASEAN, Australian, and Indian markets. Employing APARCH and using MSCI indices we find a significant positive impact of Yuan's depreciation on the conditional variances of Japanese, ASEAN and Australian equity markets. When USD-CNY exchange rate depreciates by 0.25 percent or more, volatility in the Chinese equity market causes a significant positive impact on the conditional volatility in the Japanese and Australian equity markets, though with some lag. USD-CNY exchange rate movements strongly influence the ASEAN equity markets across all time frames. The findings may enable investors to manage their portfolios of equity markets under consideration in the presence or absence of USD-CNY movements.
\end{abstract}

Keywords: China, Information Contents, Stock Return, Transmission, Volatility

JEL classification: G01, G15

\section{Introduction}

With growing integration across the international economies, the stock markets impound quickly the financial information available in both domestic as well as international markets. Price discovery can be denoted as the speed at which an asset's price reacts to new information in the market ${ }^{5}$. Apart from price discovery, conditional volatility also acts as another information transmission mechanism, whereby information in one stock market has an impact on another country's stock market owing to growing linkages between the worldwide financial markets $\frac{14,20,21}{}$. In order to enhance or at least maintain the value of their equity portfolios, investing community needs to be well versed with the effects of one financial market (forex) of a nation on the other financial markets (equity markets) of different nations, at least in the same region. There is a large body of literature investigating the return-volatility transmission or spillover effects between the equity markets across different countries for instance, Bhar \& Nikolova ${ }^{2}$, Bianconi et al., , Bekirosv ${ }^{1}$, Evgenii \& Elena ${ }^{11}$, Lehkonen \& Heimonen ${ }^{17}$ and Syriopoulos et al. ${ }^{23}$, Singh \& Singh ${ }^{22}$ and so on).

Most of the studies have reported significant volatility transmission effects owing to ever-increasing trading as well as financial linkages between the international economies. In this regard, the present study extends this relationship between the Chinese and other neighbouring equity markets while simultaneously considering Chinese Yuan movements in question. This study attempts to gather the response of international equity markets toward Chinese equity market when there are extreme movements observed in the US dollar (USD) to Chinese Yuan's (CNY) exchange rate. The impact of foreign exchange rates on the domestic stock markets is difficult to rule out. Related literature has tried to find out the relationship shared between the exchange rates and stock markets ${ }^{8,12,15,18,19}$. 
As speed of information dissemination has become unbelievably fast, therefore, we conjecture that at least for the short term, the exchange rate movements may rapidly have an impact on the domestic stock price movements via diverse direct as well as indirect channels. There are two approaches channelling this relationship: 'flow oriented' and 'stock oriented' approaches. Under the former approach proposed by Dornbusch and Fischer ${ }^{10}$, exchange rate movements affect international competitiveness further having an impact on real output and firms' performance. The firms' operating performance gets reflected in their stock prices. On the other hand, under the 'stock oriented' approach proposed by Branson ${ }^{6}$ and Frankel ${ }^{13}$, it is expected that stock prices have an impact on the exchange rates due to wealth and capital inflows. The present study follows the 'flow oriented' approach, wherein, we attempt to examine the response of international equity markets toward Chinese market's equity volatility around extreme exchange rate movements. The latter approach will further help us in teasing out both 'direct' as well as 'indirect' responses of neighbouring equity markets toward extreme exchange rate movements in China - where Chinese equity market is modelled to be playing a moderating role in extending the same. Under this, we attempt to examine the relative strength of volatility in Chinese equity market volatility in explaining conditional variance in the neighbouring equity markets, especially during the extreme exchange rate movements.

Chinese economy is the second largest economy with a huge reliance on international trade to fund its capital resources Caporale et al. ${ }^{7}$, thereby supporting the impact of USD-CNY exchange rates on the domestic stock market volatility. A natural question arises that how this Chinese stock market volatility (during extreme exchange rate movements) influence international equity markets in consideration. The study bears practical implications for the market participants, especially institutional investors in their attempt to manage their equity portfolios. The analysis focuses on the impact of Chinese equity market volatility on the conditional volatilities of four major equity markets (Japanese, Association of Southeast Asian Nations [ASEAN], Australian, and Indian stock markets) bearing strong trade as well as geographical linkages with the Chinese economy. Moreover, all these economies contribute significantly to China's overall imports. The latter impact is captured by specifically considering the extreme USD-CNY's exchange rate movements during the sample period. The study employs Asymmetric Power
ARCH (APARCH) model for generating ex-ante conditional variances, using daily closing values of the equity markets.

The results report a significant impact of the Chinese equity market on other international equity markets (except for India) around extreme movements in USD$\mathrm{CNY}$ exchange rate. We take up 0.25 percent or more, i.e. a quarter percent increase (currency depreciation) in USD-CNY's exchange rate as an extreme movement (market event) on any given day. The depreciation of the Chinese exchange rate increases international competitiveness of the Chinese goods; however, on the other hand, it also reduces earnings of the countries exporting goods and services to China amidst augmenting import prices followed by the sluggish demand scenarios. Considering dominant stance of the Chinese economy, a quarter percent or more increase in its exchange rate is quite reasonable to be regarded as extreme exchange rate movements. Furthermore, this depreciation of Chinese exchange rate is also capable of promoting 'currency war' across the international shores causing depreciation of other currencies in order to sustain competitiveness. These events also raise certain concerns on governance and transparency issues expected on the part of Chinese monetary authorities for sustainable and consistent flow of international capital. As a priori, one would expect these events to have an impact on the respective stock prices and volatility. The investigation of short-term interrelationships among equity volatilities provides useful insights to the market participants and policy-makers by signalling potential informational inefficiencies and asset mispricing scenarios ${ }^{16}$.

The rest of the paper is organised as follows: Section 2 discusses empirical framework, Section 3 reports empirical findings, and lastly Section 4 concludes the paper.

\section{Empirical Framework}

The data comprises continuously compounding gross index returns $\left[\mathrm{R}_{\mathrm{t}}=\log \left(\mathrm{P}_{\mathrm{t}} / \mathrm{P}_{\mathrm{t}-1}\right){ }^{*} 100\right]$ of Morgan Stanley Capital International (MSCI) equity indices of Chinese, Japanese, ASEAN, Australian and Indian economies. The span of daily data ranges from $27^{\text {th }}$ March, 2012 to $24^{\text {th }}$ March, 2017, i.e., a period of five years expressed in USD terms. The period is special with respect to China's recent steps in the country's financial system. China steps up efforts to internationalize the Yuan by allowing all firms in the country to pay for imports and exports in Yuan ${ }^{\mathrm{a}}$ from 
March 2012 that is why we have started our sample period from this time. The methodology follows two steps: firstly, the study estimates the conditional volatility of each equity market via the APARCH $(1,1)$ model ${ }^{9}$. The model accounts for potential asymmetric response of equity markets' volatility to positive and negative market shocks. The latter asymmetric response is technically termed as the 'leverage effects'. This model is a flexible extension of the classic Generalized Autoregressive Conditional Heteroskedastic (GARCH) model Bollerslev ${ }^{4}$, Kenourgios et al. ${ }^{16}$. It also provides flexibility to the conditional variance specification by determining the power of returns for which the volatility pattern is the optimal one. The volatility equation is as follows:

$$
\sigma_{t}^{\delta}=w+\alpha\left(\left|\varepsilon_{t-1}\right|-\gamma \varepsilon_{t-1}\right)^{\delta}+\beta \sigma_{t-1}^{\delta}
$$

Where $\varepsilon_{t}$ is the vector of zero 'mean' and white noises from the return equation, $\gamma(-1<\gamma<1)$ represents the leverage effect in the market, $\alpha$ and $\beta$ capture the impact of recent market shock and past conditional variance on the current ones respectively, while the power term parameter $\delta$ is a Box-Cox transformation of standard deviation $\sigma_{t}^{\delta}$ and may takes finite positive values. It may be noted that one day lagged returns are also appended into the 'mean' equations of the respective equity markets excluding the Chinese and Australian equity markets as per the Partial Autocorrelation Functions (PACFs). Because all the return indices are leptokurtic in nature, APARCH models are employed assuming student-t distribution of the error terms. Secondly, the conditional variances are sampled in pairs $(i, j)$ in order to quantify the impact of exchange rate movements on the volatility of other international equity markets. The study creates five dummy variables. These dummy variables are equal to unity for: 1 . One day before and one day after $(-1,+1)$, 2 . One day before and two days after $(-1,+2), 3$. One day before and three days after $(-1,+3), 4$. One day before and four days after $(-1,+4)$, and 5 . One day before and five days after $(-1,+5)$ extreme exchange rate movements, and zero otherwise. These dummy variables attempt to capture the response of international equity markets toward Chinese equity market's volatility across different time periods around the extreme exchange rate movements, i.e., whenever USD-CNY's exchange rate depreciates by 0.25 percent or more, then the event is regarded as an extreme event. These five dummy variables capture the latter responses for the coming five trading days after the event (depreciation of USD-CNY exchange rate). In order to control for the impact of one day before the depreciation day events: one day before markings (-1) are also appended into the five dummy variables. Following

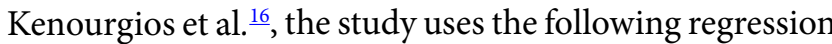
equations in order to identify any direct or indirect effects of exchange rate depreciation on the volatility dynamics of the international equity markets:

$$
\begin{aligned}
\hat{h_{i, t}} & =\delta_{0}+\delta_{1} \hat{h_{i, t-1}}+\delta_{2} \hat{h_{j, t-1}}+\delta_{3} D_{t-1} \hat{h_{i, t-1}} \\
& +\delta_{4} D_{t-1} \hat{h_{j, t-1}}+\delta_{5} D_{t}+\delta_{6} D W+\varepsilon_{t}
\end{aligned}
$$

Where $\hat{h_{i, t}}$ is the estimated conditional variance of each international equity market (Japan, ASEAN, Australia and India) derived from the APARCH $(1,1)$ model. $\delta_{0}$ is a constant term, $\delta_{1}$ is the Autoregressive (AR) term added to capture the impact of one day past conditional variance on the current one; evidenced from significant first-order serial correlation results, $\delta_{2}$ indicates the volatility transmission from the Chinese equity market (j) to other international equity markets (i) during the full sample period. For each of the five time horizons, $D_{t}$ is the dummy variable that corresponds to the days when the USD-CNY's exchange rate depreciates by 0.25 percent or more. The coefficient $\delta_{3}$ captures the impact of one day lagged volatility in the $i^{\text {th }}$ market itself on the current conditional variance around the days of Yuan's depreciation, whereas, the coefficient captures volatility transmission (indirect effect of exchange rate movements) from the Chinese equity market (j) to the $i^{\text {th }}$ market around the extreme exchange rate movements. The dummy coefficient $\delta_{5}$ also captures the 'direct' effect of the exchange rate movements on the volatility of the respective $i^{\text {th }}$ markets. Lastly, the dummy coefficient $\delta_{6}$ captures the day of the week (DW) effects in order to control for any trading days' based market anomalies. The study uses the Newey-West autocorrelation and heteroskedasticity consistent covariance matrix estimator for the purpose of overall regression analysis. Only one day lagged values are included in the regression models in order to ensure a parsimonious framework while controlling for differences in trading hours between the respective nations. 
RETURN_CHINA

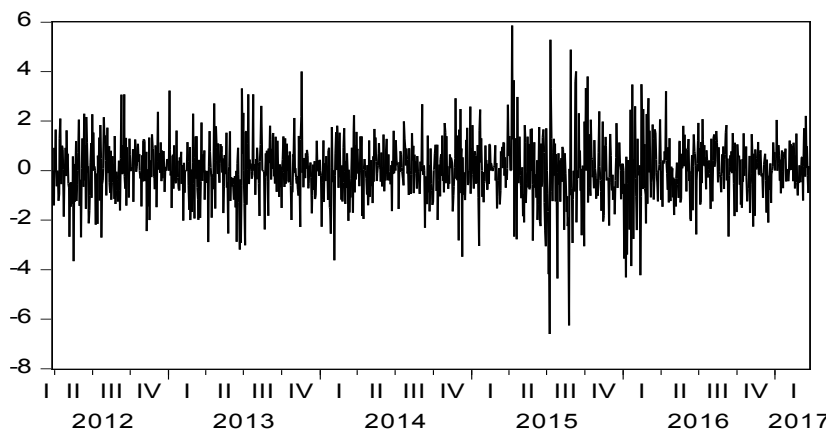

RETURN_ASEAN

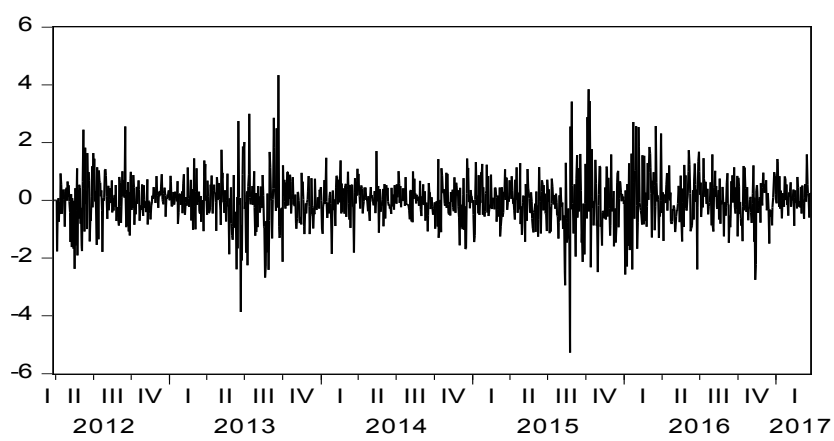

RETURN_JAPAN

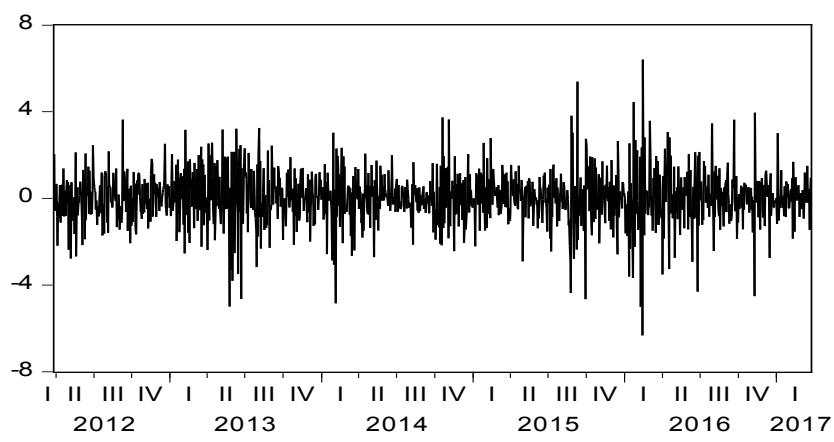

RETURN_AUSTRALIA

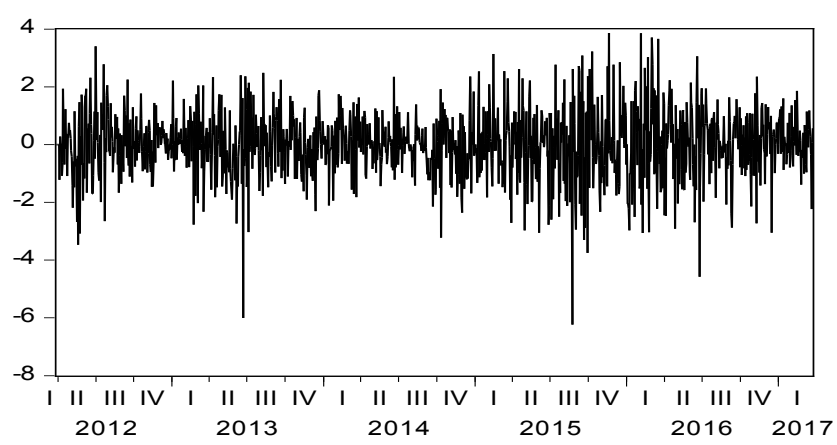

RETURN_INDIA

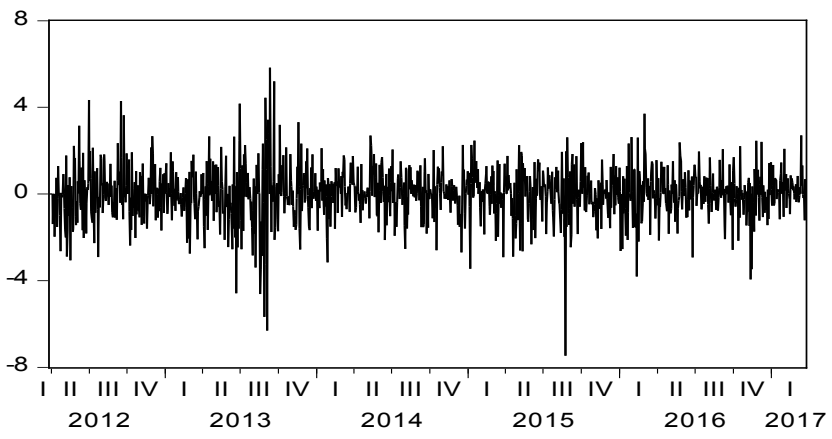

Source: Authors' Computations.

Figure 1. Index Returns

\section{Empirical Findings and Discussion}

Figure 1 is the graphical presentation of the return indices. All the indices are highly volatile, wherein large changes are followed by larger and small changes are followed by the smaller ones. This volatility clustering phenomenon justifies the application of GARCH based models. Table 1 reports descriptive statistics of the respective return indices during the full sample period. On an average, the highest average returns are observed in case of the Japanese equity market, whereas the ASEAN equity markets are found to be the least volatile markets with negative average returns. The Australian equity market also recorded negative returns during the full sample period. All the indices are negatively skewed with a greater probability of negative returns as compared to the positive ones. Both the kurtosis values as well as JarqueBera test statistics report leptokurtic and non-normal distribution of the respective index returns. This exhibits that all the equity markets provide opportunity to their investors to earn abnormal returns. For the application of 
Table 1. Index Returns - Descriptive Statistics

\begin{tabular}{|c|c|c|c|c|c|}
\hline Descriptive & China & Japan & ASEAN & Australia & India \\
\hline Mean & 0.009807 & 0.020644 & -0.010158 & -0.001455 & 0.014858 \\
\hline Sigma & 1.199819 & 1.212355 & 0.814052 & 1.144482 & 1.182560 \\
\hline Skewness & -0.149737 & -0.189970 & -0.013291 & -0.289387 & -0.334964 \\
\hline Kurtosis & 5.759602 & 5.792399 & 6.995878 & 4.698260 & 6.568339 \\
\hline Jarque-Bera & 418.6432 & 431.5070 & 867.5809 & 174.9026 & 716.2136 \\
\hline Probability & 0.000000 & 0.000000 & 0.000000 & 0.000000 & 0.000000 \\
\hline Observations & 1304 & 1304 & 1304 & 1304 & 1304 \\
\hline ADF test & $-33.747^{\star}$ & $-44.056^{\star}$ & $-31.914^{*}$ & $-35.173^{\star}$ & $-33.581^{\star}$ \\
\hline KPSS & $0.052^{\star}$ & $0.050^{*}$ & $0.064^{\star}$ & $0.076^{*}$ & $0.051^{\star}$ \\
\hline ARCH F-statistic $(10)$ & $11.774^{* *}$ & $16.302^{\star *}$ & $19.434^{* *}$ & $11.304^{\star *}$ & $11.318^{\star *}$ \\
\hline
\end{tabular}

Source: Authors' Computations; ${ }^{\star}$ Stationary at $5 \%$ level; ${ }^{* *}$ Significant ARCH effects at $5 \%$ level.

Table 2. APARCH Model Results

\begin{tabular}{|c|c|c|c|c|c|}
\hline Parameters & China & Japan & ASEAN & Australia & India \\
\hline$c$ & $\begin{array}{c}0.047^{\star} \\
(2.495)\end{array}$ & $\begin{array}{c}0.051^{\star} \\
(3.601)\end{array}$ & $\begin{array}{c}0.012^{\star} \\
(3.013)\end{array}$ & $\begin{array}{c}0.026^{*} \\
(3.920)\end{array}$ & $\begin{array}{c}0.047^{\star} \\
(3.865)\end{array}$ \\
\hline$\alpha$ & $\begin{array}{c}0.027 \\
(1.313) \\
\end{array}$ & $\begin{array}{l}0.089^{*} \\
(5.670)\end{array}$ & $\begin{array}{l}0.054^{*} \\
(2.690) \\
\end{array}$ & $\begin{array}{c}0.057^{\star} \\
(4.538)\end{array}$ & $\begin{array}{c}0.065^{\star} \\
(5.247)\end{array}$ \\
\hline$\beta$ & $\begin{array}{c}0.909^{*} \\
(41.377)\end{array}$ & $\begin{array}{c}0.895^{\star} \\
(41.039)\end{array}$ & $\begin{array}{c}0.936^{*} \\
(68.919)\end{array}$ & $\begin{array}{c}0.934^{*} \\
(73.870)\end{array}$ & $\begin{array}{c}0.917^{\star} \\
(48.960)\end{array}$ \\
\hline$\gamma$ & $\begin{array}{l}0.331^{\star} \\
(3.059)\end{array}$ & $\begin{array}{l}0.948^{*} \\
(9.118) \\
\end{array}$ & $\begin{array}{l}0.950^{*} \\
(2.439)\end{array}$ & $\begin{array}{l}0.923^{\star} \\
(4.497)\end{array}$ & $\begin{array}{c}0.999^{*} \\
(111.867)\end{array}$ \\
\hline$\delta$ & $\begin{array}{l}2.968^{\star} \\
(3.162)\end{array}$ & $\begin{array}{l}0.663^{\star} \\
(3.441) \\
\end{array}$ & $\begin{array}{l}1.182^{\star} \\
(4.161)\end{array}$ & $\begin{array}{l}0.914^{\star} \\
(3.845)\end{array}$ & $\begin{array}{l}0.703^{\star} \\
(3.264)\end{array}$ \\
\hline$D f$ & $\begin{array}{c}5.989^{*} \\
(5.633)\end{array}$ & $\begin{array}{l}6.389^{*} \\
(5.563)\end{array}$ & $\begin{array}{l}5.850^{*} \\
(5.539)\end{array}$ & $\begin{array}{c}9.783^{*} \\
(3.869)\end{array}$ & $\begin{array}{l}5.071^{\star} \\
(5.805)\end{array}$ \\
\hline Q (10) & 15.045 & 7.015 & 13.596 & 8.008 & 11.072 \\
\hline $\mathrm{Q}^{2}(10)$ & 12.595 & 4.275 & 5.061 & 6.945 & 16.222 \\
\hline
\end{tabular}

Source: Authors' Computations; ${ }^{\star}$ Significant at $5 \%$ level.

Note: Figures in the parentheses show t-statistic.

inferential statistics, the financial time series are required to be stationary in nature. In other words, the financial data should follow a 'mean' reversion behaviour. The present study employs Augmented Dickey-Fuller (ADF) and Kwiatkowski-Phillips-Schmidt-Shin (KPSS) test statistics in order to check for stationarity of the return indices. It is quite apparent from the reported test statistics that all the return indices are found to be stationary in nature at 5 percent significance level. On the other hand, the study also reports ARCH effects in order to justify the application of APARCH models in empirical terms. All test statistics report existence of ARCH effects in the residuals derived from the 'mean' equations regressed only against the constant terms. The GARCH based models are found to be efficient in capturing these $\mathrm{ARCH}$ effects in the residuals; evidenced from literature over a period of time.

The total number of observations is 1304 . Now we move on to APARCH $(1,1)$ model results for the respective equity markets. Table 2 reports APARCH $(1,1)$ model results assuming student-t distribution of error terms. The results show that except for the Chinese equity market, all the ARCH and GARCH parameters are statistically significant with non-negative coefficients and their sum is below unity. The ARCH parameter or recent market shocks are found to be statistically insignificant in the context of the Chinese equity market. The past conditional variances play a substantive role in channelling current conditional variances. The leverage term is also statistically significant for 
Table 3. Regression Model Results

(a) Japan

\begin{tabular}{|c|c|c|c|c|c|}
\hline Parameters & $(-1,+1)$ & $(-1,+2)$ & $(-1,+3)$ & $(-1,+4)$ & $(-1,+5)$ \\
\hline Constant & $\begin{array}{c}0.080^{*} \\
(1.998)\end{array}$ & $\begin{array}{c}0.084^{*} \\
(2.005)\end{array}$ & $\begin{array}{c}0.084^{*} \\
(2.050)\end{array}$ & $\begin{array}{c}0.087^{*} \\
(2.066)\end{array}$ & $\begin{array}{c}0.085^{*} \\
(2.031)\end{array}$ \\
\hline $\boldsymbol{\delta}_{\mathbf{1}}$ & $\begin{array}{c}0.904^{*} \\
(42.789)\end{array}$ & $\begin{array}{c}0.908^{*} \\
(43.285)\end{array}$ & $\begin{array}{c}0.912^{*} \\
(45.109)\end{array}$ & $\begin{array}{c}0.910^{*} \\
(45.613)\end{array}$ & $\begin{array}{c}0.909^{*} \\
(44.871)\end{array}$ \\
\hline $\boldsymbol{\delta}^{2}$ & $\begin{array}{c}0.037^{* *} \\
(1.666)\end{array}$ & $\begin{array}{c}0.036 \\
(1.643)\end{array}$ & $\begin{array}{c}0.032 \\
(1.530)\end{array}$ & $\begin{array}{c}0.033 \\
(1.563)\end{array}$ & $\begin{array}{c}0.035 \\
(1.613)\end{array}$ \\
\hline $\boldsymbol{\delta}_{\mathbf{3}}$ & $\begin{array}{c}-0.032 \\
(-0.747)\end{array}$ & $\begin{array}{c}-0.066 \\
(-1.299)\end{array}$ & $\begin{array}{c}-0.119^{*} \\
(-2.590)\end{array}$ & $\begin{array}{c}-0.104^{*} \\
(-2.118)\end{array}$ & $\begin{array}{c}-0.101^{*} \\
(-2.764)\end{array}$ \\
\hline $\boldsymbol{\delta}_{4}$ & $\begin{array}{c}0.033 \\
(0.871)\end{array}$ & $\begin{array}{c}0.026 \\
(0.712)\end{array}$ & $\begin{array}{c}0.106^{*} \\
(2.002)\end{array}$ & $\begin{array}{c}0.084^{* *} \\
(1.687)\end{array}$ & $\begin{array}{c}0.057^{* *} \\
(1.653)\end{array}$ \\
\hline $\boldsymbol{\delta}_{\mathbf{5}}$ & $\begin{array}{c}0.048 \\
(0.991)\end{array}$ & $\begin{array}{c}0.011 \\
(0.193)\end{array}$ & $\begin{array}{c}-0.015 \\
(-0.332)\end{array}$ & $\begin{array}{c}-0.013 \\
(-0.280)\end{array}$ & $\begin{array}{c}-0.000 \\
(-0.012)\end{array}$ \\
\hline $\begin{array}{c}\text { DOW } \\
\text { effects }\end{array}$ & Yes & Yes & Yes & Yes & Yes \\
\hline Adj. $\mathbf{R}^{2}$ & 0.847 & 0.848 & 0.848 & 0.848 & 0.848 \\
\hline
\end{tabular}

(b) ASEAN

\begin{tabular}{|c|c|c|c|c|c|}
\hline Parameters & $(-1,+1)$ & $(-1,+2)$ & $(-1,+3)$ & $(-1,+4)$ & $(-1,+5)$ \\
\hline Constant & $\begin{array}{l}0.015^{\star *} \\
(1.728)\end{array}$ & $\begin{array}{l}0.016^{\star *} \\
(1.887)\end{array}$ & $\begin{array}{l}0.017^{*} \\
(2.021)\end{array}$ & $\begin{array}{l}0.016^{\star \star} \\
(1.862)\end{array}$ & $\begin{array}{c}0.017^{*} \\
(1.990)\end{array}$ \\
\hline$\delta_{1}$ & $\begin{array}{c}0.976^{*} \\
(81.066)\end{array}$ & $\begin{array}{c}0.975^{\star} \\
(80.919)\end{array}$ & $\begin{array}{c}0.975^{*} \\
(82.977)\end{array}$ & $\begin{array}{c}0.974^{*} \\
(82.476)\end{array}$ & $\begin{array}{c}0.974^{*} \\
(79.670)\end{array}$ \\
\hline$\delta_{2}$ & $\begin{array}{c}-0.002 \\
(-0.593)\end{array}$ & $\begin{array}{c}-0.002 \\
(-0.478)\end{array}$ & $\begin{array}{c}-0.002 \\
(-0.667)\end{array}$ & $\begin{array}{c}-0.001 \\
(-0.299)\end{array}$ & $\begin{array}{c}-0.002 \\
(-0.512)\end{array}$ \\
\hline$\delta_{3}$ & $\begin{array}{l}-0.094^{*} \\
(-2.598)\end{array}$ & $\begin{array}{l}-0.079^{*} \\
(-2.087)\end{array}$ & $\begin{array}{l}-0.094^{*} \\
(-3.188)\end{array}$ & $\begin{array}{l}-0.057^{* *} \\
(-1.798)\end{array}$ & $\begin{array}{c}-0.059 \\
(-1.340)\end{array}$ \\
\hline$\delta_{4}$ & $\begin{array}{l}0.048^{*} \\
(2.114)\end{array}$ & $\begin{array}{l}0.035^{\star *} \\
(1.945)\end{array}$ & $\begin{array}{c}0.055^{*} \\
(3.284)\end{array}$ & $\begin{array}{c}0.020 \\
(0.976)\end{array}$ & $\begin{array}{l}0.039^{* *} \\
(1.794)\end{array}$ \\
\hline$\delta_{5}$ & $\begin{array}{l}0.037^{*} \\
(2.647)\end{array}$ & $\begin{array}{c}0.022 \\
(1.589)\end{array}$ & $\begin{array}{c}0.001 \\
(0.116)\end{array}$ & $\begin{array}{c}0.020 \\
(1.432)\end{array}$ & $\begin{array}{c}0.005 \\
(0.447)\end{array}$ \\
\hline $\begin{array}{l}\text { DOW } \\
\text { effects }\end{array}$ & Yes & Yes & Yes & Yes & Yes \\
\hline Adj. $R^{2}$ & 0.943 & 0.943 & 0.943 & 0.943 & 0.943 \\
\hline
\end{tabular}

(c) Australia

\begin{tabular}{|c|c|c|c|c|c|}
\hline Parameters & $(-1,+1)$ & $(-1,+2)$ & $(-1,+3)$ & $(-1,+4)$ & $(-1,+5)$ \\
\hline Constant & $\begin{array}{l}0.037^{*} \\
(2.437)\end{array}$ & $\begin{array}{l}0.040^{*} \\
(2.652)\end{array}$ & $\begin{array}{l}0.042^{*} \\
(2.757)\end{array}$ & $\begin{array}{l}0.039^{*} \\
(2.629)\end{array}$ & $\begin{array}{c}0.042^{*} \\
(2.740)\end{array}$ \\
\hline$\delta_{1}$ & $\begin{array}{c}0.953^{\star} \\
(90.325)\end{array}$ & $\begin{array}{c}0.956^{\star} \\
(91.148)\end{array}$ & $\begin{array}{c}0.958^{*} \\
(95.399)\end{array}$ & $\begin{array}{c}0.957^{*} \\
(94.389)\end{array}$ & $\begin{array}{c}0.958^{*} \\
(94.534)\end{array}$ \\
\hline$\delta_{2}$ & $\begin{array}{c}0.010 \\
(1.102)\end{array}$ & $\begin{array}{c}0.008 \\
(0.919)\end{array}$ & $\begin{array}{c}0.006 \\
(0.725)\end{array}$ & $\begin{array}{c}0.007 \\
(0.889)\end{array}$ & $\begin{array}{c}0.006 \\
(0.770)\end{array}$ \\
\hline$\delta_{3}$ & $\begin{array}{c}0.021 \\
(0.551)\end{array}$ & $\begin{array}{c}-0.029 \\
(-0.616)\end{array}$ & $\begin{array}{c}-0.066^{* *} \\
(-1.842)\end{array}$ & $\begin{array}{c}-0.041 \\
(-1.180)\end{array}$ & $\begin{array}{c}-0.066 \\
(-1.564)\end{array}$ \\
\hline$\delta_{4}$ & $\begin{array}{c}-0.001 \\
(-0.017)\end{array}$ & $\begin{array}{c}0.030 \\
(0.667)\end{array}$ & $\begin{array}{c}0.087^{*} \\
(2.554)\end{array}$ & $\begin{array}{c}0.042 \\
(1.177)\end{array}$ & $\begin{array}{l}0.076^{* \star} \\
(1.880)\end{array}$ \\
\hline$\delta_{5}$ & $\begin{array}{c}0.038 \\
(1.421)\end{array}$ & $\begin{array}{c}0.011 \\
(0.516)\end{array}$ & $\begin{array}{c}-0.018 \\
(-0.892)\end{array}$ & $\begin{array}{c}0.018 \\
(0.806)\end{array}$ & $\begin{array}{c}-0.006 \\
(-0.371)\end{array}$ \\
\hline $\begin{array}{l}\text { DOW } \\
\text { effects }\end{array}$ & Yes & Yes & Yes & Yes & Yes \\
\hline Adj. $R^{2}$ & 0.930 & 0.930 & 0.930 & 0.930 & 0.930 \\
\hline
\end{tabular}

\section{(d) India}

\begin{tabular}{|c|c|c|c|c|c|}
\hline Parameters & $(-1,+1)$ & $(-1,+2)$ & $(-1,+3)$ & $(-1,+4)$ & $(-1,+5)$ \\
\hline Constant & $\begin{array}{l}0.077^{\star} \\
(3.242)\end{array}$ & $\begin{array}{l}0.076^{*} \\
(3.172)\end{array}$ & $\begin{array}{l}0.079^{\star} \\
(3.272)\end{array}$ & $\begin{array}{l}0.076^{\star} \\
(3.143)\end{array}$ & $\begin{array}{l}0.080^{*} \\
(3.295)\end{array}$ \\
\hline$\delta_{1}$ & $\begin{array}{c}0.937^{\star} \\
(58.635)\end{array}$ & $\begin{array}{c}0.937^{\star} \\
(58.478)\end{array}$ & $\begin{array}{c}0.935^{\star} \\
(58.612)\end{array}$ & $\begin{array}{c}0.936^{\star} \\
(58.574)\end{array}$ & $\begin{array}{c}0.935^{*} \\
(58.596)\end{array}$ \\
\hline$\delta_{2}$ & $\begin{array}{c}0.003 \\
(0.434)\end{array}$ & $\begin{array}{c}0.004 \\
(0.481)\end{array}$ & $\begin{array}{c}0.003 \\
(0.435)\end{array}$ & $\begin{array}{c}0.004 \\
(0.438)\end{array}$ & $\begin{array}{c}0.004 \\
(0.449)\end{array}$ \\
\hline$\delta_{3}$ & $\begin{array}{c}-0.050 \\
(-1.102)\end{array}$ & $\begin{array}{c}-0.052 \\
(-1.506)\end{array}$ & $\begin{array}{c}-0.005 \\
(-0.113)\end{array}$ & $\begin{array}{c}-0.042 \\
(-1.120)\end{array}$ & $\begin{array}{c}-0.021 \\
(-0.526)\end{array}$ \\
\hline$\delta_{4}$ & $\begin{array}{c}0.040 \\
(1.416)\end{array}$ & $\begin{array}{c}0.024 \\
(1.196)\end{array}$ & $\begin{array}{c}0.030 \\
(1.174)\end{array}$ & $\begin{array}{c}0.028 \\
(1.074)\end{array}$ & $\begin{array}{c}0.027 \\
(1.150)\end{array}$ \\
\hline$\delta_{5}$ & $\begin{array}{c}0.014 \\
(0.599)\end{array}$ & $\begin{array}{c}0.021 \\
(0.731)\end{array}$ & $\begin{array}{c}-0.032 \\
(-1.631)\end{array}$ & $\begin{array}{c}0.019 \\
(0.685)\end{array}$ & $\begin{array}{c}-0.013 \\
(-0.643)\end{array}$ \\
\hline $\begin{array}{l}\text { DOW } \\
\text { effects }\end{array}$ & Yes & Yes & Yes & Yes & Yes \\
\hline Adj. $R^{2}$ & 0.878 & 0.879 & 0.879 & 0.879 & 0.878 \\
\hline
\end{tabular}

Source: Authors' Computations; ${ }^{* * *}$ Significant at $5 \%$ and $10 \%$ level respectively. Note: Figures in the parentheses show t-statistic. 
CHINA

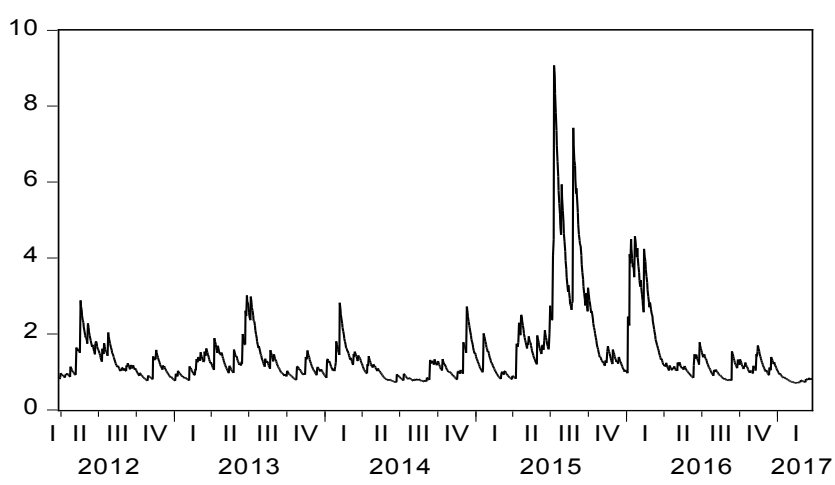

ASEAN

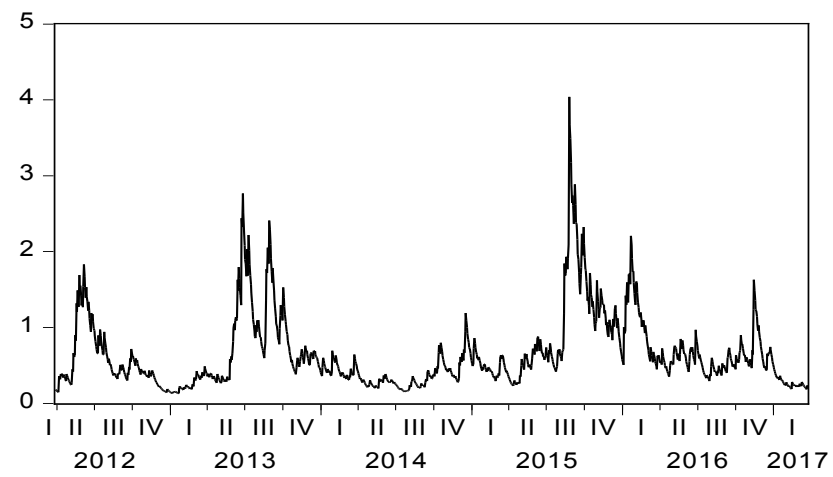

JAPAN

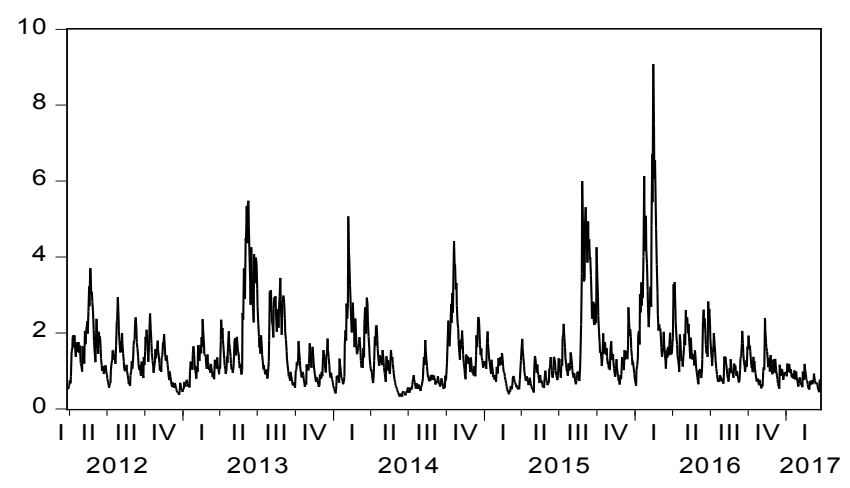

AUSTRALIA

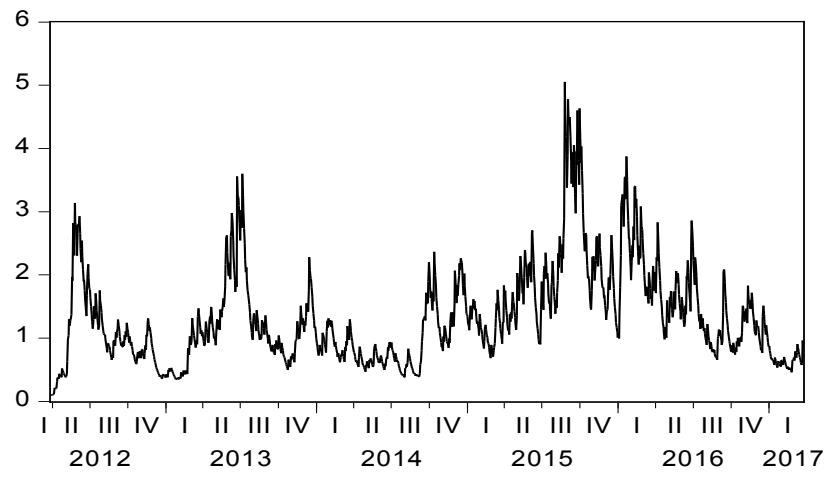

INDIA

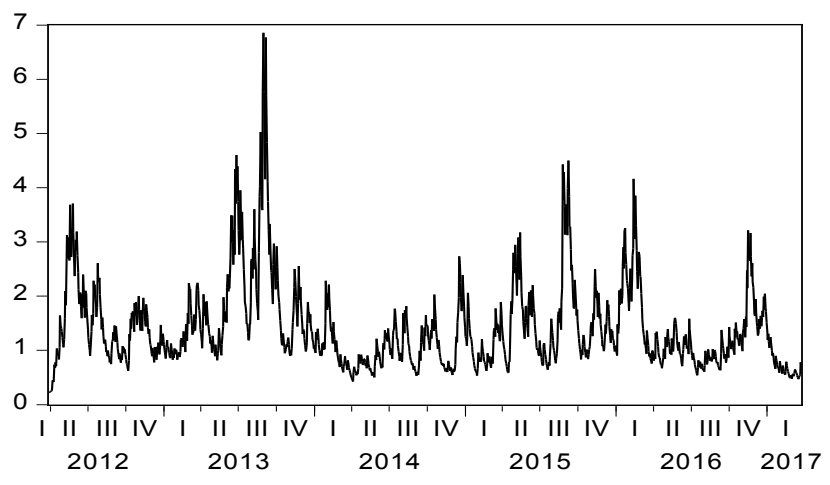

Source: Authors' Computations.

Figure 2. Conditional Variances

all the markets indicating an asymmetric response of volatilities to negative market shocks.

The power terms $(\delta)$ are positive and statistically significant at 5 percent significance level. Moreover, the student- $t$ degrees of freedom parameters (Df) are also statistically significant thereby supporting the specifications of the respective APARCH models. Finally, the Ljung-Box Q statistics in the standardized and squared standardized residuals indicate the absence of linear and non-linear (ARCH effects) serial correlations. Further, Figure 2 reports conditional variances of the respective equity markets. The Chinese, Japanese, ASEAN and Australian equity markets are found to be highly volatile during the third quarter of the year 2015, when the monetary authorities in China unleashed a bolder move of drastically depreciating their currency against the US Dollar. 
On the other hand, Indian equity market is highly volatile during the third quarter of the year 2013, when the US taper tantrums or reversal of quantitative easing measures erupted worldwide. Table 3 reports univariate regression model results for different pairs $(i, j)$. Here, $i^{\text {th }}$ element stands for the respective international equity markets and $j^{\text {th }}$ element stands for the Chinese equity market. In case of Japan Table 3(a), the autoregressive coefficients $\left(\delta_{1}\right)$ are found to be statistically significant having greater magnitude impact on the current conditional variance. There is direct effect of conditional variance in the Chinese equity market $\left(\delta_{2}\right)$ on the Japanese equity market after one day. Interestingly, volatility in the Chinese equity market (around extreme movements) starts having a significant positive impact on the conditional variance in the Japanese equity market after three days of depreciation in the USD$\mathrm{CNY}$ exchange rate $\left(\delta_{4}\right)$. However, the magnitude of the same reduces in the coming $4^{\text {th }}$ and $5^{\text {th }}$ day after the depreciation event. One day past volatility in the Japanese market itself $\left(\delta_{3}\right)$ plays a counter-balancing act by reducing volatility coming from the Chinese shores after three days of the depreciation event. The results do not support direct effect of USD-CNY depreciation events on the conditional variances in the Japanese equity market $\left(\delta_{5}\right)$.

In case of ASEAN markets Table 3(b), all the autoregressive coefficients are found to be significant across all the time periods $\left(\delta_{1}\right)$. There is no direct effect of the Chinese equity market's volatility $\left(\delta_{2}\right)$ on the conditional variance in the ASEAN equity markets. The volatility in the Chinese equity market (around extreme movements) has a statistically significant impact on the current conditional variances in the ASEAN equity markets after one, two, three and five days of depreciation in the USD-CNY exchange rate $\left(\delta_{4}\right)$. The coefficients are positive in nature indicating an increasing impact of volatility in the Chinese equity market on conditional volatility in the ASEAN equity markets around extreme exchange rate movements. Moreover, this impact is found to be more or less persistent for the coming five trading days. The findings bear strong implications for the market participants to rein in risks during the depreciation of
USD-CNY exchange rate. On a similar note, volatility in the ASEAN markets itself $\left(\delta_{3}\right)$ plays a counter-balancing role having an impact on the current conditional variances across all the time horizons. The coefficients are negative and most of them are statistically significant at 5 and 10 percent levels. Interestingly, there is also a direct effect $\left(\delta_{5}\right)$ of extreme exchange rate movements on the conditional variances in the ASEAN equity markets. The impact is observed only for one day after the depreciation event.

In case of Australia Table 3(c), all the autoregressive coefficients are found to be statistically significant $\left(\delta_{1}\right)$ . There is no direct effect of the Chinese equity market on the conditional variance in the Australian equity market $\left(\delta_{2}\right)$. On an interesting note, conditional variance in the Chinese equity market has a significant impact on the Australian market volatility after three and five days of extreme exchange rate movements $\left(\delta_{4}\right)$. The coefficients are positive indicating an increasing impact of the Chinese market volatility on the Australian one. There is also counter balancing response of the Australian equity market after three days of the market event $\left(\delta_{3}\right)$. Similarly, the Australian equity market is not directly influenced by the exchange rate movements across all the time frames $\left(\delta_{5}\right)$. In case of India Table 3(d), only autoregressive terms are observed to be having a significant impact on the current conditional variance $\left(\delta_{1}\right)$. There are no direct as well as indirect effects of the exchange rate movements recorded on the Indian equity market volatility across all the time frames. All the significant autoregressive coefficients signify existence of volatility clustering phenomenon in the respective international equity markets.

\section{Concluding Remarks}

In this globalised financial system, portfolio managers are required to track events taking place in both domestic as well as international economies. The Chinese economy is on the path of achieving several structural economic initiatives in the wake of attaining 'market economy' status. Consequent to this, a greater degree of transparency is expected from the Chinese monetary authorities at the time of setting foreign exchange reference rates. This may promote sustainable capital flows across the interna- 
tional financial markets. In this regard, the present study investigates whether the extreme depreciation of USD$\mathrm{CNY}$ exchange rate causes direct or indirect effects on the conditional variances in international equity markets - Japanese, ASEAN, Australian, and Indian equity markets. The study employs APARCH and other univariate regression based models for capturing conditional variances, and relationship between the respective equity markets. Using daily closing values of MSCI indices and dummy variables spread across different time frames, the results report significant positive impact of the Chinese market volatility on the conditional variances of Japanese, ASEAN and Australian equity markets. For instance, when USD-CNY exchange rate depreciates by 0.25 percent or more, volatility in the Chinese equity market causes significant positive impact on the conditional volatility in the Japanese equity market after three days. The latter impact continues for the coming two more days albeit with a lesser magnitude.

We find that ASEAN equity markets are strongly influenced by USD-CNY exchange rate movements. There are both direct as well as indirect positive effects of these market movements on the ASEAN equity markets' volatility. Volatility in the Chinese equity market augments volatility in the ASEAN equity markets after one day of the market event. This indirect effect of exchange rate movements continues for the coming four more days. On a similar note, Australian equity market gets influenced by volatility in the Chinese equity market around the days of extreme depreciation in the USD-CNY's exchange rate. The results do not support any impact (both direct as well as indirect) on the Indian equity market. As per the latest trade statistics of International Monetary Fund (IMF), Japan, ASEAN nations, and Australia are strong trading partners of China, whereby the contribution of all the former economies is quite larger in the China's overall import numbers. Consequently, a significant impact of Yuan's depreciation is reasonably expected on their respective equity markets. Whereas, on the other hand, the contribution (rank) of India is moderately lower as compared to the other undertaken economies. The study adds to the existing literature by simultaneously considering exchange rate movements and international equity volatility interactions.

Owing to increasing trade as well as financial linkages between the international economies, the findings may provide opportunities to the Australian and Japanese investors to add some forex related insight to their risk management strategies and portfolios in order to garner expected returns while tracking USD-CNY exchange rate movements. Both the latter markets respond after three days of extreme movements in the USD-CNY exchange rate - thereby giving a sufficient time period to the investors to devise market strategies. However, volatility in the ASEAN equity markets respond immediately (after one day) towards volatility in the Chinese equity market around extreme movements in the exchange rate. There are also direct effects causing positive volatility in the ASEAN equity markets. These findings bear strong implications for the market participants in the ASEAN equity markets.

\section{References}

1. Bekiros SD. Decoupling and the spillover effects of the US Financial Crisis: Evidence from the BRIC Markets. IRFA 2014; 33:58-69. https://doi.org/10.1016/j.irfa.2013.07.007

2. Bhar R, Nikolova B. Analysis of mean and volatility spillovers using BRIC Countries, Regional and World Equity Index Returns. JEI. 2007; 22(2):369-81. https://doi org/10.11130/jei.2007.22.2.369

3. Bianconi M, Yoshino JA, Sousa MO. BRIC and the U.S. financial crisis: An empirical investigation of stock and bond markets. Emerg. Mark. Rev. 2013; 14:76-109. https:// doi.org/10.1016/j.ememar.2012.11.002

4. Bollerslev T. Generalized autoregressive conditional heteroskedasticity. J Econom. 1986; 31:307-27. https://doi. org/10.1016/0304-4076(86)90063-1

5. Booth GG, So WR, Tse Y. Price discovery in the German equity index derivatives markets. J. Futures Mark. 1999; 9(6):619-43. https://doi.org/10.1002/(SICI)10969934(199909)19:6<619::AID-FUT1>3.0.CO;2-M

6. Branson WH. Macroeconomic determinants of real exchange rate Risk. R. J. Herring, editor. Managing Foreign Exchange Rate Risk. Cambridge: Cambridge University Press; 1983. p. 33-74.

7. Caporale GM, Sova A, Sova R. Trade flows and trade specialisation: The case of China. China Economic Power. 2015; 34:261-73. https://doi.org/10.1016/j.chieco.2015.03.010

8. Diamandis PF, Drakos AA. Financial liberalization, exchange rates and stock prices: Exogenous Shocks in Four Latin America Countries. J Policy model. 2011; 33:381-94. https://doi.org/10.1016/j.jpolmod.2010.11.004

9. Ding Z, Granger CWJ, Engle RF. A long memory property of stock market returns and a new model. JEmpir Financ. 1993; 1:83-106. https://doi.org/10.1016/0927-5398(93)90006-D

10. Dornbusch R, Fischer S. Exchange rates and the current account. Am Econ Rev. 1980; 70:960-71. 
11. Evgenii G, Elena F. Internal and external spillover effects for the BRIC countries: Multivariate GARCH-in-mean approach. Research in International Business and Finance. 2014; 31:32-45. https://doi.org/10.1016/j.ribaf.2013.11.002

12. Fowowe B. The relationship between stock prices and exchange rates in South Africa and Nigeria: structural breaks analysis. International Review of Applied Economics. 2015; 29(1):1-14. https://doi.org/10.1080/02692171.2014.933786

13. Frankel JA. Monetary and portfolio balance models of exchange rate determination. J. S. Bhandari, B. H. Putnam, editors. Economic Interdependence and Flexible Exchange Rates Cambridge: MIT Press; 1983. p. 84-115.

14. Gagnon 1, Karolyi AG. Price and volatility transmisison across borders. Financial Markets, Institutions and Instruments. 2006; 17(3):107-58. https://doi.org/10.1111/ j.1468-0416.2006.00115.x

15. Granger CWJ, Huang B-N, Yang C.W. A bivariate causality between stock prices and exchange rates: Evidence from Recent Asian Flu. The Quarterly Review of Economics and Finance. 2000; 40:337-54. https://doi.org/10.1016/S10629769(00)00042-9

16. Kenourgios D, Papadamou S, Dimitriou D. Intraday exchange rate volatility transmissions across QE announcements. FRL. 2015; 14:128-34. https://doi.org/10.1016/j. frl.2015.05.007

17. Lehkonen H, Heimonen K. Timescale-dependent stock market comovement: BRICs vs. developed markets. J Empir Financ 2014; 28:90-103. https://doi.org/10.1016/j. jempfin.2014.06.002
18. Lin $\mathrm{CH}$. The comovement between exchange rates and stock prices in the Asian Emerging Markets. International Review of Economics and Finance. 2012; 22:161-72. https://doi.org/10.1016/j.iref.2011.09.006

19. Phylaktis K, Ravazzolo F. Stock prices and exchange rate dynamics. J. Int. Money Finance. 2005; 24:1031-53. https:// doi.org/10.1016/j.jimonfin.2005.08.001

20. Rittler D. Price discovery and volatility spillovers in the European Union emissions trading scheme: A highfrequency analysis. JBF. 2012; 36(3):774-85. https://doi. org/10.1016/j.jbankfin.2011.09.009

21. Singh A, Kaur P. A short note on information transmissions across US-BRIC Equity Markets: Evidence from Volatility Spillover Index. Quant. Econ. J. 2017; 15(1):197-208. https://doi.org/10.1007/s40953-016-0047-2

22. Singh A, Singh M. Cross country co-movement in equity markets after the US financial crisis: India and major economic giants. Journal of Indian Business Research. 2016; 8(2):98-121. https://doi.org/10.1108/JIBR-08-2015-0089

23. Syriopoulos T, Makram B, Boubaker A. Stock market volatility spillovers and portfolio hedging: BRICS and the financial crisis. IRFA. 2015; 39:7-18. https://doi. org/10.1016/j.irfa.2015.01.015

\section{Note}

${ }^{a}$ https://www.reuters.com/article/us-china-yuan-timeline/timeline-chinasreforms-of-yuan-exchange-rate-idUSBRE83D03820120414 